Original Research Paper

\title{
A Study about Impact of Customer Characteristics on Online Purchase Behavior in Indian Context
}

\author{
Upasana Kanchan and Naveen Kumar \\ School of Management, Gautam Buddha University, \\ Greater Noida-201310, Uttar Pradesh, India
}

\author{
Article history \\ Received: 30-6-2015 \\ Revised: $17-8-2015$ \\ Accepted: 29-9-2015 \\ Corresponding Author: \\ Upasana Kanchan \\ School of Management, \\ Gautam Buddha University, \\ Greater Noida-201310 Uttar \\ Pradesh, India \\ Tel: +91-9411469220 \\ E-mail: Kanchan_upasana@yahoo.com
}

\begin{abstract}
The recent growth of e-commerce and the consumer's increasing interest in purchasing over the net have significantly changed the landscape of Indian retail market. Today customers are inclined to accept the changes and keep their eyes on the benefits they can obtain from online retailers. The recent example of changing consumer purchase pattern is the flipkart's 'Big Billion day' Sale. The growth in online sales can be partially attributed to the Internet's advantages of providing large amounts of information quickly and inexpensively and it's growing accessibility. Yet, to reach its full potential, business owners who use ecommerce as a distribution channel need a clearer understanding of who buys online, what they buy online, why they buy online and how the non-Internet buyer can be transformed into an online buyer in order to increase online sales. The purpose of this study is to understand and analyze the factors effecting online purchase decisions of Indian customer. The paper attempts to identify the determinants of online purchase intentions of youths in Indian context. Based on extensive literature review, factors effecting online purchase intentions, antecedents of service quality and consumer attitudes were identified and a structured-non-disguised questionnaire was prepared. The data was collected through survey of 200 students of graduation and post-graduation courses in Moradabad region of Uttar Pradesh. The questionnaire contained questions about consumer demographics, security and privacy concerns, technological familiarity, past online shopping experiences and intentions to buy various types of products through internet in future. The findings of the study indicate that customer online purchase intentions are significantly related to their gender, education, age, security concern, technological familiarity and past online purchase frequency. Consumer buying behavior is also affected by product type, purchase frequency and expensiveness. Their purchase decisions are also found to be related with the online retailer's services like return, refund and delivery services. The framework of the research enhances understanding of the factors affecting customer online shopping behaviour, helps in profiling typical Indian online shoppers and may help e-marketers developing more specific marketing strategies to increase e-commerce sales.
\end{abstract}

Keywords: Online Shopping Intentions, Online Shopping, Customer Characteristics, E-Retailing, E-Commerce

\section{Introduction}

Today, internet acts as a channel through which millions of people communicate, perform research, find entertainment and most recently buy and sell products and services. Infact, online shopping is one of the most popular activities that take place on internet. Here are some statistics to validate the above statement.
India currently has a base of 150 million internet users which accounts to be the third largest in the world (Source: Business World Marketing Whitebook 2013-14)

Users accessing the web through mobile devices has almost doubled every year since 2009 .

The size of e-commerce market in India is worth around Rs 9,500 crore, out of which the pure play online shopping market is worth Rs 1,300 crore. 
While online shopping globally is growing at around $8-10 \%$, in India the growth rate is upwards of $30 \%$ (source: Economic Times).

Indian direct-to-customer e-commerce market is likely to double in size to more than $\$ 3$ billion within three years and could grow to reach $\$ 15$ billion by 2017 as said by Avnish Bajaj, co-founder and director of Matrix Partners India.

India's online customer base of around 20 million shoppers could increase as much as $1400 \%$ and reach 300 million shoppers within 10 years.

Social media activity is a strong indicator of how much shoppers will buy, both online and in stores. There are 62.7 million Facebook users in India, representing $68 \%$ of the country's online population, according to SocialBakers, which tracks activity on social networks.

Although the country recently has 150 million internet users, but only approximately 10 million users transact online ( $7 \%$ of online users). This shows that ecommerce industry is still in its nascent stage in India. Though online shopping is very common outside India, its growth in Indian market, which is a large customer market, is still not in line with the global market. This is the reason that triggered the idea of conducting a research in this area.

There is a huge opportunity for e-retailers as the average annual growth of this market is estimated around $70 \%$ by Internet and Mobile Association of India. The no. of online buyers is expected to increase to approximately 38 million users transacting online by 2015. Today, an Indian shopping online may do two to three transactions per month. In just another two to three years as the market grows and matures, the average online shopper could be doing four to five transactions per month.

Therefore industry should focus on the factors that affect the buying behavior of Indian customers. Although many studies have shown that customer characteristics are important when it comes to online shopping, but majority of those researches are performed outside India. To fill this gap, the following research is proposed to examine how different customer characteristics affect customer purchase intentions while shopping online in India.

\section{Literature Review}

Adoption of online shopping in India: last three decades have seen a phenomenal growth of World Wide Web. A wide acceptance of internet technology in the field of business has changed the traditional retail format to the new form popularly known as internet shopping or online shopping. The internet is a platform that provides the customer with purchase characteristics as no other medium. There are certain characteristics which make internet a more convenient and attractive place to shop for consumers as compared to the traditional way of shopping, such as the facility to view and purchase products any time, visualize their needs with products, compare between different brands of products, discuss products with other consumers, option to pay on delivery etc.

Online-shopping is the process consumers go through when they decide to shop on the internet. The internet has developed into a new distribution channel (Hollensen, 2004) and the evolution of this channel, e-commerce, has been identified by Smith and Rupp (2003) to be the most significant contribution of the information revolution. Today, internet has developed into a highly competitive market and in order to have an impact on customers and to retain them, it is the first step to identify certain influencing aspects when purchasing online, these can be regarded as factors. The proposed research will be focused on identifying and analyzing these factors.

Consumer characteristics and its impact on online shopping: Many previous researches have been done in the field of e-commerce. In a study conducted by Kunz (1997) on online shopping, it was found that customer demographics affect the purchase intentions in a significant manner. The results of the study says that men are more likely to purchase via internet and those who intend to shop online are likely to be young. The study also explored that people living in large metropolitan areas do less shopping online as compared to those who live in suburban areas.

Few other studies (Fram and Grady, 1997; Mehta and Sivadas, 1995; Sultan and Henrichs, 2000) also reported that gender, marital status, residential location, age, education and household income are important predictors of internet purchasing.

Another research conducted by Donthu and Garcia (1999) for consumer characteristics related to online shopping, it was found that consumers who seek convenience and variety do more shopping online. They also found that such people are also more innovative and spontaneous. In a study by, Sui and Cheng (2000) it was found that economic benefits, product availability, security risk are also important factors in classifying online shoppers.

Zhou et al. (2007) discovered that customer traits, internet self efficacy, prior online shopping experience, shopping orientations, economic benefit perception, risk perception are some of the factors affecting online shopping acceptance of customers.

Customer characteristics can be explained in following categories: cultural, characteristics, social characteristics, personal characteristics and psychological characteristics. Cultural characteristics are developed by three features- culture, sub culture and social class (Hawkins et al., 1995; Armstrong and Kotler, 2007; Wu, 2003), while social characteristics may be defined with the help of reference groups, 
family, social roles and status (Armstrong and Kotler, 2007; Wu, 2003). Personal characteristics are divided into Age and Life-Cycle Stage, Occupation, Economic Situation, Lifestyle, Personality and Self-concept (Kotler and Armstrong, 2007; Hawkins et al., 1995; Wu, 2003). Last but not the least psychological characteristics can be defined by Motivation, Perception, Learning and Beliefs and Attitudes (Kotler and Armstrong, 2007; Wu, 2003).

These customer characteristics will be studied specifically for the online customers. The characteristics will be studied to segment the online consumer by analyzing:

- The customer's demographics

- Life patterns concerning Online Behaviour, such as how much the consumer uses the Internet and for what purposes.

- Prior experiences have also been identified to be relevant for what Beliefs and Attitudes the customer has towards online shopping and are therefore also important for the research.

These are the customer characteristics that are relevant for this research and need to be identified in order to find out who the online customer is and what affects him when shopping online.

\section{Research Objectives and Hypothesis}

Following objectives have been framed for the research:

- To know about the purpose of using internet

- To find popular e-tailing websites

- To know about the most popular category of item purchased online

- To study the impact of demographic characteristics of customers on their online purchase pattern

Based on the literature review following hypothesis have been framed:

$\mathrm{H}_{1}$ : As compared to females, males are more likely to engage in online shopping.

$\mathrm{H}_{2}$ : Age is positively related to online buying.

$\mathrm{H}_{3}$; Education is positively related to online shopping.

$\mathrm{H}_{4}$ : Income is positively related with online shopping.

$\mathrm{H}_{5}$ : The greater the concern for security and privacy issues, the lower is the likelihood of a consumer engaging in online shopping.

$\mathrm{H}_{6}$ : Consumer familiarity with the technology positively influences their online buying decision.

$\mathrm{H}_{7}$ : Higher the frequency of online purchases made in the past, more likely such customers would be engaging in online shopping in future.

\section{Research Methodology}

The present research work is descriptive and analytical based on empirical observation and comprehensive survey. In order to test the above framed hypotheses, a survey of consumers residing in Moradabad region was carried out with the help of a 'structured non-disguised' questionnaire. A pilot study was also conducted on a sample of 15 respondents. Some modifications, additions and deletion of questions are made according to the results of pilot study and suggestions of subject experts. Then the final study was conducted on a sample of 200 respondents in the Moradabad district.

The sample was drawn using convenience sampling method. The questionnaire developed for the study was personally administered to 200 respondents in the month of February-April 2014. Questions were prepared using nominal, ordinal and likert scales. Percentage method, Correlation analysis and Chi-Square test were used for analyzing the responses.

\section{Analysis of Study}

Following Tables 1 to 8 shows the summary of responses given by respondents:

Table 1. Classification of respondents on the basis of gender (In percentage)

\begin{tabular}{ll}
\hline Male & 59 \\
Female & 41 \\
\hline
\end{tabular}

Table 2. Classification on the basis of Age (No. of respondents)

\begin{tabular}{ll}
\hline Less than 15 years & $10(5 \%)$ \\
$15-30$ years & $25(12.5 \%)$ \\
$30-45$ years & $120(60 \%)$ \\
Above 45 years & $45(22.5 \%)$ \\
\hline
\end{tabular}

Table 3. Classification on the basis of education level (No. of respondents)

Under graduate 15

Graduates $\quad 25$

Post graduates $\quad 40$

$\begin{array}{lr}\text { Professionally qualified } & 120\end{array}$

Table 4. Average Monthly Income (No. of respondents)

Less than 15 thousand 45

15-30 thousand 90

$30-50$ thousand $\quad 40$

More than 50 thousand

25

Table 5. Purpose of using internet (In percentage)

\begin{tabular}{ll}
\hline Communication & 29 \\
Information gathering & 22 \\
Entertainment & 27 \\
Shopping & 21 \\
\hline
\end{tabular}


Table 6. Popular e-tailing websites (In percentage)

\begin{tabular}{ll}
\hline Flipkart & 23 \\
Jabong & 12 \\
Homeshop 18 & 21 \\
Snapdeal & 10 \\
Ebay & 21 \\
Yebhi & 70 \\
Others & 60 \\
\hline
\end{tabular}

Table 7. Popular categories of items purchased online (in percentage)

\begin{tabular}{ll}
\hline Books/cds/software & 22 \\
Apparels & 19 \\
Electronics/mobiles/home appliances & 14 \\
Jewellery & 90 \\
Tickets & 21 \\
Travel packages & 90 \\
Others & 60 \\
\hline
\end{tabular}

Table 8. Factors motivating to shop online (in percentage)

Time saving and convenient 24

$24 * 7$ available $\quad 16$

Discounts/price deals $\quad 10$

Easy Price comparison $\quad 18$

Cash on delivery 12

30 days return policy $\quad 60$

Wider Variety 12

\section{Hypothesis Testing}

For testing various hypotheses, Correlation analysis and Chi-Square test has been performed on the collected data. Results are presented below in the various tables.

\section{Gender and Online Purchase Frequency}

Chi-Square test was used to assess the impact of gender on online purchase frequency. The results are presented in the following Table 9 and 10.

It can be observed that gender significantly affects the online purchase frequency $(p<0.01)$. It can therefore be concluded that males are more likely to engage in online shopping.

\section{Age and Online Purchase Frequency}

Correlation analysis has been used to see whether there exists any relationship between age and online purchase frequency of the respondents. The following Table 11 and 12 shows the results.

The result clearly indicates that there is a significant correlation among age of respondents and their online purchase frequency. It can be concluded that age is positively related to online purchase frequency.

\section{Education and Online Purchase Frequency}

Correlation analysis has been used to see whether there exists any relationship between education of respondents and online purchase frequency of the respondents. The following Table 13 and 14 shows the results.
The result clearly indicates that there is a significant correlation between education of respondents and their online purchase frequency. It therefore can be concluded that education level is positively related to online purchase frequency.

\section{Income and Online Purchase Frequency}

Correlation analysis has been used to check whether income of respondents affects their online purchase frequency or not. The following Tables 15 and 16 represent the results.

Since correlation is found to be significant therefore results can be interpreted as Average monthly income is positively correlated with the online purchase frequency of customers.

\section{Security Concern and Online Purchase Frequency}

Correlation analysis is performed to know how online purchase frequency is related to the security concern of respondents while shopping online. The following Table 17 and 18 shows the results.

The results clearly indicate that there is a negative correlation between the concern for security and online purchase frequency. Therefore, it can be interpreted that the higher will be the concern for security, the less no. of online purchases will be made by the customers.

\section{Consumer Familiarity with Technology and Online Purchase Frequency}

Correlation analysis was performed to check the relationship between technology familiarity and online purchase frequency. The following Table 19 and 20 summarizes the results.

The value of $r$ is significant at 99\% confidence level. Therefore it can be interpreted that consumer familiarity with the technology positively influences their online buying decision

\section{Past Online Purchase Frequency and Future Online Purchase Intentions}

Chi-square test has been performed to assess the impact of past online purchase frequency on future online purchase intentions. The following Tables 21 and 22 show the results.

It can be observed that past online purchase frequency significantly affects the future online purchase intention $(p<0.01)$. It can therefore be concluded that higher the frequency of online purchases made in the past, more likely such customers would be engaging in online shopping in future. 
Upasana Kanchan and Naveen Kumar / American Journal of Economics and Business Administration 2015, 7 (3): 130.138 DOI: 10.3844/ajebasp.2015.130.138

Table 9. Gender and past online purchase frequency cross-tabulations

\begin{tabular}{|c|c|c|c|c|c|}
\hline & & & Gende & & \\
\hline & & & Male & Female & Total \\
\hline & Never & Count & 6 & 15.0 & 21.0 \\
\hline & & Expected Count & 12.4 & 8.6 & 21.0 \\
\hline & $1-5$ times & Count & 40.0 & 36.0 & 76.0 \\
\hline & & Expected Count & 44.8 & 31.2 & 76.0 \\
\hline Past online purchase & 5-10 times & Count & 43.0 & 16.0 & 59.0 \\
\hline frequency for last year & & Expected Count & 34.8 & 24.2 & 59.0 \\
\hline & $10-15$ times & Count & 19.0 & 9.0 & 28.0 \\
\hline & & Expected Count & 16.5 & 11.5 & 28.0 \\
\hline & More than 15 times & Count & 10.0 & 6.0 & 16.0 \\
\hline & & Expected Count & 9.4 & 6.6 & 16.0 \\
\hline Total & & Count & 118.0 & 82.0 & 200.0 \\
\hline & & Expected Count & 118.0 & 82.0 & 200.0 \\
\hline
\end{tabular}

Table 10. Chi-square tests

\begin{tabular}{|c|c|c|c|}
\hline & Value & $\mathrm{df}$ & $\begin{array}{l}\text { Asymp. Sig. } \\
\text { (2-sided) }\end{array}$ \\
\hline Pearson Chi-square & $15.001^{\mathrm{a}}$ & 4 & 005.000 \\
\hline Likelihood ratio & 15.170 & 4 & 0.004 \\
\hline Linear-by-linear & 7.875 & 1 & 0.005 \\
\hline \multicolumn{4}{|l|}{ Association } \\
\hline $\mathrm{N}$ of valid cases & 200.000 & & \\
\hline
\end{tabular}

Table 11. Age and past online purchase frequency cross-tabulations

\begin{tabular}{|c|c|c|c|c|c|c|}
\hline & & \multicolumn{4}{|l|}{ Age } & \multirow[b]{2}{*}{ Total } \\
\hline & & Less than $15 \mathrm{yr}$ & $15-30 \mathrm{yr}$ & $30-45 y r$ & above $45 \mathrm{yr}$ & \\
\hline Past Online purchas & never & 10 & 14 & 1 & 0 & 25 \\
\hline frequency for & $1-5$ times & 0 & 11 & 45 & 19 & 75 \\
\hline \multirow[t]{3}{*}{ last year } & 5-10 times & 0 & 0 & 37 & 19 & 56 \\
\hline & 10-15 times & 0 & 0 & 22 & 6 & 28 \\
\hline & more than 15 times & 0 & 0 & 16 & 0 & 16 \\
\hline Total & & 10 & 25 & 121 & 44 & 200 \\
\hline
\end{tabular}

Table 12. Correlations

\begin{tabular}{llrr}
\hline \multicolumn{1}{l}{ Table 12. Correlations } & & $\begin{array}{l}\text { Past online purchase } \\
\text { frequency for last year }\end{array}$ & age \\
\hline Past online purchase year & Pearson correlation & 1.000 & $0.401^{* *}$ \\
frequency for last & Sig. (2-tailed) & & 0.000 \\
& $\mathrm{~N}$ & 200.000 & 200.000 \\
age & Pearson correlation & $401.000^{* *}$ & 1.000 \\
& Sig. (2-tailed) & 0.000 & 200.000 \\
\hline
\end{tabular}

**. Correlation is significant at the 0.01 level (2-tailed)

Table 13. Education level and past online purchase frequency cross-tabulations

\begin{tabular}{|c|c|c|c|c|c|c|}
\hline & & \multicolumn{4}{|c|}{ Education level } & \multirow[b]{2}{*}{ Total } \\
\hline & & $\begin{array}{l}\text { Under } \\
\text { graduate }\end{array}$ & Graduate & $\begin{array}{l}\text { Post } \\
\text { graduate }\end{array}$ & $\begin{array}{l}\text { Professionally } \\
\text { qualifie }\end{array}$ & \\
\hline \multirow{5}{*}{$\begin{array}{l}\text { Past } \\
\text { purchase for last year frequency }\end{array}$} & never & 15 & 10 & 0 & 0 & 25 \\
\hline & $1-5$ times & 0 & 15 & 24 & 36 & 75 \\
\hline & 5-10 times & 0 & 0 & 18 & 38 & 56 \\
\hline & 10-15 times & 0 & 0 & 0 & 28 & 28 \\
\hline & more than & 0 & 0 & 0 & 16 & 16 \\
\hline Total & 15 time & 15 & 25 & 42 & 118 & 200 \\
\hline
\end{tabular}


Table 14. Correlations

\begin{tabular}{llcr}
\hline & & $\begin{array}{l}\text { Past online purchase } \\
\text { frequency for last year }\end{array}$ & $\begin{array}{c}\text { Education } \\
\text { level }\end{array}$ \\
\hline Past online purchase & Pearson Correlation & 1.000 & $0.657^{* *}$ \\
frequency for last year & Sig. (1-tailed) & & 0.000 \\
& $\mathrm{~N}$ & 200.000 & 200.000 \\
education level & Pearson Correlation & $0.657^{* *}$ & 1.000 \\
& Sig. (1-tailed) & 0.000 & 200.000 \\
\hline **. & $\mathrm{N}$ & 200.000 &
\end{tabular}

**. Correlation is significant at the 0.01 level (1-tailed)

Table 15. Average monthly income and past online purchase frequency cross-tabulations

\begin{tabular}{|c|c|c|c|c|c|c|c|}
\hline & & Past on & Irchase fre & $y$ for la & & & \\
\hline & & never & $1-5$ times & $\begin{array}{l}5-10 \\
\text { times }\end{array}$ & $\begin{array}{l}10-15 \\
\text { times }\end{array}$ & $\begin{array}{l}\text { more than } \\
15 \text { times }\end{array}$ & Total \\
\hline & $\begin{array}{l}\text { less than } \\
15 \mathrm{~K}\end{array}$ & 25 & 20 & 1 & 0 & 0 & 46 \\
\hline avg_monthly_income & $15-30 \mathrm{k}$ & 0 & 31 & 31 & 22 & 6 & 90 \\
\hline & $30-50 \mathrm{~K}$ & 0 & 20 & 5 & 5 & 10 & 40 \\
\hline & above $50 \mathrm{~K}$ & 0 & 4 & 19 & 1 & 0 & 24 \\
\hline Total & & 25 & 75 & 56 & 28 & 16 & 200 \\
\hline
\end{tabular}

Table 16. Correlations

\begin{tabular}{llcr}
\hline Table 16. Correlations & & $\begin{array}{c}\text { Past online purchase } \\
\text { frequency for last year }\end{array}$ & $\begin{array}{c}\text { Avg. monthly } \\
\text { income }\end{array}$ \\
\hline Past online purchase & Pearson Correlation & 1.000 & $0.401^{* *}$ \\
frequency for last year & Sig. (2-tailed) & & 0.000 \\
& N & 200.000 & 200.000 \\
Avg. monthly income & Pearson Correlation & $0.401^{* *}$ & 1.000 \\
& Sig. (2-tailed) & 0.000 & 200.000 \\
\hline
\end{tabular}

**. Correlation is significant at the 0.01 level (2-tailed)

Table 17. Security concern and past online purchase frequency cross-tabulations

\begin{tabular}{|c|c|c|c|c|c|c|c|}
\hline & \multicolumn{7}{|c|}{ How much concerned are you about security and privacy while purchasing online } \\
\hline & & $\begin{array}{l}\text { Not at all } \\
\text { concerned }\end{array}$ & 2.00 & 3.00 & 4.00 & $\begin{array}{l}\text { Very much } \\
\text { concerned }\end{array}$ & Total \\
\hline Past online & never & 7 & 5 & 2 & 0 & 11 & 25 \\
\hline purchase & $1-5$ times & 10 & 25 & 25 & 10 & 5 & 75 \\
\hline \multirow{3}{*}{$\begin{array}{l}\text { frequency for } \\
\text { last year }\end{array}$} & 5-10 times & 8 & 21 & 23 & 2 & 2 & 56 \\
\hline & 10-15 times & 12 & 14 & 0 & 1 & 1 & 28 \\
\hline & $\begin{array}{l}\text { More than } \\
15 \text { times }\end{array}$ & 16 & 0 & 0 & 0 & 0 & 16 \\
\hline Total & & 53 & 65 & 50 & 13 & 19 & 200 \\
\hline
\end{tabular}

Table 18. Correlations

\begin{tabular}{|c|c|c|c|}
\hline & & $\begin{array}{l}\text { Past online purchase } \\
\text { frequency for last year }\end{array}$ & $\begin{array}{l}\text { Security } \\
\text { concern }\end{array}$ \\
\hline Past online purchase & Pearson Correlation & 1.000 & $-0.443^{* *}$ \\
\hline \multirow[t]{2}{*}{ frequency for last year } & Sig. (2-tailed) & & 0.000 \\
\hline & $\mathrm{N}$ & 200.000 & 200.000 \\
\hline \multirow[t]{3}{*}{ Security Concern } & Pearson Correlation & $-0.443^{* *}$ & 1.000 \\
\hline & Sig. (2-tailed) & 0.000 & \\
\hline & $\mathrm{N}$ & 200.000 & 200.000 \\
\hline
\end{tabular}

**. Correlation is significant at the 0.01 level (2-tailed) 
Table 19. Technology familiarity and past online purchase frequency cross-tabulations

\begin{tabular}{|c|c|c|c|c|c|c|c|}
\hline & & \multicolumn{5}{|c|}{ Past online purchase frequency for last year } & \multirow[b]{2}{*}{ Total } \\
\hline & & never & $1-5$ times & 5-10 times & 10-15 times & $\begin{array}{l}\text { more than } \\
15 \text { times }\end{array}$ & \\
\hline \multirow[t]{3}{*}{$\begin{array}{l}\text { Technology } \\
\text { familiarity }\end{array}$} & $\begin{array}{l}\text { Not so } \\
\text { familiar }\end{array}$ & 17 & 0 & 1 & 0 & 0 & 18 \\
\hline & Average knowledge & 8 & 48 & 9 & 4 & 0 & 69 \\
\hline & Very much familiar & 0 & 27 & 46 & 24 & 16 & 113 \\
\hline \multicolumn{2}{|r|}{ 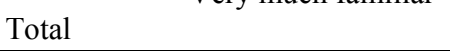 } & 25 & 75 & 56 & 28 & 16 & 200 \\
\hline \multicolumn{8}{|c|}{ Table 20. Correlations } \\
\hline & & & & \multicolumn{2}{|c|}{$\begin{array}{l}\text { Technology } \\
\text { familiarity }\end{array}$} & \multicolumn{2}{|c|}{$\begin{array}{l}\text { Past online purchase } \\
\text { frequency for last year }\end{array}$} \\
\hline \multirow{3}{*}{\multicolumn{2}{|c|}{$\begin{array}{l}\text { Past online purchase } \\
\text { frequency for last year }\end{array}$}} & \multirow{2}{*}{\multicolumn{2}{|c|}{$\begin{array}{l}\text { Pearson Correlation } \\
\text { Sig. (2-tailed) }\end{array}$}} & \multicolumn{2}{|c|}{1.000} & \multicolumn{2}{|c|}{$0.646^{* *}$} \\
\hline & & & & \multirow{2}{*}{\multicolumn{2}{|c|}{200.000}} & \multicolumn{2}{|c|}{0.000} \\
\hline & & \multicolumn{2}{|c|}{$\mathrm{N}$} & & & \multicolumn{2}{|c|}{200.000} \\
\hline \multirow{3}{*}{\multicolumn{2}{|c|}{ Technology familiarity }} & Pearsor & lation & \multicolumn{2}{|c|}{$0.646^{* *}$} & \multirow{2}{*}{\multicolumn{2}{|c|}{1.000}} \\
\hline & & \multicolumn{2}{|c|}{ Sig. (2-tailed) } & \multicolumn{2}{|c|}{0.000} & & \\
\hline & & $\mathrm{N}$ & & \multicolumn{2}{|c|}{200.000} & \multicolumn{2}{|c|}{200.000} \\
\hline
\end{tabular}

**. Correlation is significant at the 0.01 level (2-tailed)

Table 21. Future purchase intentions and past online purchase frequency cross-tabulations

\begin{tabular}{|c|c|c|c|c|c|}
\hline & & & \multicolumn{2}{|c|}{$\begin{array}{l}\text { I will purchase goods/services } \\
\text { online in future }\end{array}$} & \multirow[b]{2}{*}{ Total } \\
\hline & & & Yes & no & \\
\hline \multirow{9}{*}{$\begin{array}{l}\text { Past online purchaseCount } \\
\text { frequency for last year }\end{array}$} & \multirow[t]{2}{*}{ never } & Count & 6.0 & 19.0 & 25.0 \\
\hline & & Expected Count & 14.3 & 10.8 & 25.0 \\
\hline & \multirow{2}{*}{$1-5$ times } & Count & 26.0 & 49.0 & 75.0 \\
\hline & & Expected Count & 42.8 & 32.3 & 75.0 \\
\hline & \multirow[t]{2}{*}{ 5-10 times } & Count & 43.0 & 13.0 & 56.0 \\
\hline & & Expected Count & 31.9 & 24.1 & 56.0 \\
\hline & \multirow[t]{2}{*}{$10-15$ times } & Count & 24.0 & 4.0 & 28.0 \\
\hline & & Expected Count & 16.0 & 12.0 & 28.0 \\
\hline & \multirow[t]{4}{*}{ more than 15 times } & Count & 15.0 & 1.0 & 16.0 \\
\hline \multirow{3}{*}{ Total } & & Expected Count & 9.1 & 6.9 & 16.0 \\
\hline & & Count & 11.0 & 86.0 & 200.0 \\
\hline & & Expected Count & 114.0 & 86.0 & 200.0 \\
\hline
\end{tabular}

Table 22. Chi-square tests

\begin{tabular}{llll}
\hline & & df & $\begin{array}{c}\text { Asymp. Sig. } \\
(2 \text {-sided })\end{array}$ \\
\hline Pearson Chi-Square & Value & 4 & 0.000 \\
Likelihood Ratio & $53.550^{\mathrm{a}}$ & 4 & 0.000 \\
Linear-by-Linear & 57.833 & 1 & 0.000 \\
Association & 46.466 & & \\
N of Valid Cases & & & \\
\hline
\end{tabular}

\section{Findings and Implications}

The objective of this paper was to assess the impact of customer characteristics on their online shopping intentions. Based on the review of literature, a total of six customer-related factors were identified and examined in the study. Major findings of the study and their implications are as follows:

- Both the gender are likely to purchase goods/services online but as compared to females, males do more online shopping
- Most of the time people use internet for communication purpose i.e. for e-mail, chatting, social networking etc. but people also use internet for entertainment, information gathering and shopping purpose

- It has been analyzed that people in the age group between 30-45 years are more interested in doing online shopping as compared to other age groups

- Income has a positive relationship with online purchase frequency. People having higher income are more engaged in purchasing goods over internet 
- Education level of respondents was also found to be positively correlated with online purchase frequency implying that the higher the education level of people, more they have tended to prefer buying goods online

- The most popular website for online shopping was flipkart. Although many people are also aware about ebay and homeshop 18

- The most popular items purchased by people over internet are books followed by tickets and apparels

- Customers' concern for security is found to be negatively correlated with their online purchase decision. People highly concerned about security of personal information, passwords, financial transactions are less likely to do online shopping

- A positive relationship between past online purchase frequency and future online shopping intentions is observed implying that customers who purchased more products via internet in past will continue to make online purchases in future too

- Technology familiarity of the respondents is found to be positively related with past online purchase frequency

- The implications are once again that people having high knowledge of technology are more likely to shop online

The managerial implications of above findings are that the online marketers need to target their products to young and more educated customers earning higher income. Educated persons are likely to be more internet savvy and higher income enables them to purchase more online provided they are sufficiently exposed to online shopping outlets and motivated to place orders online. The findings of the study suggest that online marketers should ensure about the high security of personal information of customers and financial transactions along with providing good experience of online shopping so that customer may continue purchasing online in future also.

\section{Conclusion}

Though online shopping is very common outside India, its growth in Indian market, which is a large customer market, is still not in line with the global market. According to India B2C E-Commerce Report 2013, e-tailing accounts for less than $1 \%$ of the overall retail market in India in 2012. While it accounts for over $5 \%$ if the total retail market in China and $10 \%$ in the UK and the US. This shows that only a small fraction of internet users in India are currently online shoppers. The reason could be that it is not the technology but the way customers feel about high-tech purchasing that is holding back the development of the industry. Hence this is imperative that marketers understand the depth of customer intentions for this medium of retailing.

It can be concluded on the basis of study that online shopping is gaining popularity among people of young generation. Higher income groups and educated people are purchasing more via e-retailing websites. People have hesitations in doing online shopping due to security concerns. At the same time people are resistant to change because of technological complexity in making online purchase. Companies involved in online retailing should focus on building trust-worthy relationship between producers and customers.

\section{Acknowledgment}

Every research work has many invisible helping hands with their invaluable support and inspiration. We are thankful to our colleagues for providing their suggestions and help. We are also grateful to the management of the institute for providing infrastructural support for conducting the research.

\section{Funding Information}

Research was not funded by any organization. Authors did their own expenses for research.

\section{Author's Contributions}

Dr. Naveen Kumar: Conceptualized the idea for research, proposed design for the manuscript, reviewed critically and gave suggestions for the final manuscript.

Ms. Upasana Kanchan: Collected data both primary and secondary, analyized data and drafted it in the proper form of a research paper.

\section{Ethics}

There should not be any ethical issues over the manuscript. Researchers has conducted similar researches in different regions of india and developed separate findings for each of the region.

\section{References}

Donthu, N. and A. Garcia, 1999. The internet shopper. J. Advertising Res., 39: 52-58.

Fram, E.H. and D.B. Grady, 1997. Internet shoppers: Is there a surfer gender gap? Direct Market., 59: 46-50.

Hawkins, D., R.J. Best and K.A. Coney, 1995. Consumer Behavior: Implications for Marketing Strategy. 1st Edn., Irwin, Chicago, ISBN-10: 0256139725, pp: 649.

Hollensen, S., 2004. Global Marketing: A Decisionoriented Approach. 3rd Edn., Prentice Hall, ISBN-10: 0273678396, pp: 760. 
Kotler, P. and G. Armstrong, 2007. Principles of Marketing. 12th Edn., Prentice Hall, ISBN-10: 0132390027, pp: 736.

Kunz, M.B., 1997. On-line customers: Identifying store, product and consumer attributes which influence shopping on the Internet. PhD Thesis, University of Tennessee, Knoxville.

Mehta, R. and E. Sivadas, 1995. Direct marketing on the Internet: Ann empirical assessment of consumer attitudes. J. Direct Marketing, 9: 21-32.

Smith, A.D. and W.T. Rupp, 2003. Strategic online customer decision making: Leveraging the transformational power of the internet. Online Inform. Rev., 27: 418-432.

DOI: $10.1108 / 14684520310510055$
Sultan, F. and R.B. Henrichs, 2000. Consumer preferences for Internet services over time: initial explorations. J. Consumer Market., 17: 386-402. DOI: $10.1108 / 07363760010341036$

$\mathrm{Wu}$, S., 2003. The relationship between consumer characteristics and attitude toward online shopping. Market. Intelligence Planning, 21: 37-44.

DOI: $10.1108 / 02634500310458135$

Zhou, L., L. Dai and D. Zhang, 2007. Online shopping acceptance model-a critical survey of consumer factors in online shopping. J. Electronic Commerce Res., 8: 101-112. 